\title{
Effect of Tree-Fall Gaps on Fruit-Feeding Nymphalid Butterfly Assemblages in a Peruvian Rain Forest
}

\author{
Sylvia Pardonnet, Harald Beck, Per Milberg and Karl-Olof Bergman
}

\section{Linköping University Post Print}

\section{Tweet}

N.B.: When citing this work, cite the original article.

This is the pre-reviewed version of the following article:

Sylvia Pardonnet, Harald Beck, Per Milberg and Karl-Olof Bergman, Effect of Tree-Fall Gaps on Fruit-Feeding Nymphalid Butterfly Assemblages in a Peruvian Rain Forest, 2013, Biotropica, (45), 5, 612-619.

which has been published in final form at:

http://dx.doi.org/10.1111/btp.12053

Copyright: Wiley-Blackwell http://eu.wiley.com/WileyCDA/Brand/id-35.html

Postprint available at: Linköping University Electronic Press http://urn.kb.se/resolve?urn=urn:nbn:se:liu:diva-98221 
LRH: Pardonnet, Beck, Milberg and Bergman

RRH: Treefall Gaps and Butterfly Diversity

\section{Effect of Tree-Fall Gaps on Fruit-Feeding Nymphalid Butterfly}

\section{Assemblages in a Peruvian Rain Forest}

Sylvia Pardonnet ${ }^{1}$, Harald Beck ${ }^{2}$, Per Milberg ${ }^{1}$, and Karl-Olof Bergman ${ }^{1,3}$

${ }^{1}$ IFM Biology, Conservation Ecology Group, Linköping University, SE-581 83, Linköping,

Sweden

${ }^{2}$ Department of Biological Sciences, Towson University, 8000 York Road, Towson, MD 21252, U.S.A.

${ }^{3}$ Corresponding author; e-mail: karbe@ifm.liu.se

Received 18 October 2012; revision accepted 5 May 2013. 


\section{ABSTRACT}

One of the main natural disturbances that affects the structure of rain forests are tree falls, frequently resulting in gaps. Treefall gaps can bring drastic changes in environmental conditions compared to the undisturbed understory. We investigated the effect of treefall gaps on fruitfeeding butterfly (Nymphalidae) species assemblages in an undisturbed lowland rain forest in southeastern Peru. We used fruit-baited traps suspended $2 \mathrm{~m}$ above ground in 15 treefall gaps ranging in area from 100 to $1000 \mathrm{~m}^{2}$ and in adjacent undisturbed understory. Our data support the hypothesis that treefall gap and understory habitats are utilized by different butterfly species assemblages. There were morphological differences between gap and understory species, where the understory species had a larger wing area to thoracic volume. Vegetation structure and composition were important factors affecting the butterfly assemblages. Most of the butterfly species showed an avoidance of vines and a strong association with the presence of trees and shrubs in gaps. There were also differences among gap assemblages that increased with gap size. Some of the species that were associated with gaps have been considered as canopy species. Other gap species in the present study, however, are known to feed on fruits and/or use host plants mainly, or only, occurring in gaps, implicating that the gap assemblage is a mix of canopy species and those unique to gaps. This indicates that, in an undisturbed Amazon forest, treefall gaps may contribute to maintain species diversity by creating a mosaic of specific habitats and resources that favors different butterfly assemblages.

\section{RESUMO}

Una de las principales perturbaciones naturales que afectan a la estructura de los bosques es la caída de árboles y la creación de claros. Estos nuevos espacios pueden conllevar cambios 
drásticos en las condiciones ambientales de los claros en comparación con el sotobosque original. En nuestro estudio investigamos el efecto de la caída de árboles en la diversidad de especies de mariposas frutívoras (Nymphalidae) en un bosque tropical no perturbado de tierras bajas en el sureste de Perú. Utilizamos trampas con cebo (fruta) suspendidas a 2 metros de altura en 15 claros producidos por la caída de árboles con áreas variables desde 100 a $1.000 \mathrm{~m}^{2}$ y en áreas adyacentes del bosque no perturbado. Nuestros resultados concuerdan con la hipótesis de que los claros son utilizados por distintos ensambles de mariposas. Encontramos diferencias morfológicas entre especies de claro y especies de sotobosque, las especies de sotobosque tenían una mayor área alar en relación con su volumen torácico. La estructura y la composición de la vegetación son factores importantes para los ensambles de mariposas. La mayoría de las especies de mariposas evitaban las lianas y mostraban una fuerte asociación con la presencia de árboles y arbustos en los claros. También se observaron diferencias en los ensambles al aumentar el área de los claros. Algunas de las especies asociadas a los claros son consideradas especies del dosel. Sin embargo, otras especies de claros identificadas en nuestro estudio se alimentan de fruta y/o utilizan plantas que de manera preferencial o exclusiva se localizan en claros. Esto implica que el ensamble de claro es una mezcla de especies del dosel y de especies exclusivas de claros. En consecuencia, en un bosque amazónico no perturbado, claros en el bosque causados por la caída natural de árboles puede contribuir a mantener la diversidad de las especies mediante la creación de un mosaico de hábitats específicos y recursos que favorecen diferentes ensambles de mariposas.

Key words: Amazonia; gap dynamics; intermediate disturbances; Lepidoptera; Manu National Park; Neotropics; vine. 
THE PRINCIPAL NATURAL DISTURBANCE AFFECTING THE STRUCTURE OF RAIN FORESTS ARE TREE

FALLS that create gaps within which succession is triggered by increased light reaching the understory (Connell 1978, Whitmore 1978). Gap size can affect the environmental conditions and thereby the resulting plant community composition (Molino \& Sabatier 2001, Schnitzer \& Carson 2001, Pearson et al. 2003). A consequence of tree falls is that the tropical rain forest can be considered as a mosaic of micro-successional patches, with few areas having a species composition near equilibrium (Terborgh 1992). This mosaic has been suggested as one of the most important factors that may maintain high species diversity in tropical rain forests.

Studies on the effect of treefall gaps on animals include birds (Levey 1988) and mammals (Beck et al. 2004, Beck 2008). Insects have received less attention (Richard \& Windsor 2007), but include ants (Feener \& Schupp 1998), day-flying insects (Shelly 1988, Richard \& Windsor 2007), and butterflies (Hill et al. 2001). A number of studies have compared butterfly assemblages in unlogged forests with forest gaps created by selective logging (Willott et al. 2000, Hill \& Hamer 2004, Hamer et al. 2003, Fermon et al. 2005, Cleary et al. 2009). Forest gaps created by selective logging differ from natural gaps in that they are more frequent and larger in size (Cleary et al. 2009) and so the response of butterflies to logging gaps might not be directly applicable to natural treefall gaps. The effect of natural treefall gaps on butterfly assemblages has been studied in Asian rain forests (Hill et al. 2001) but rarely elsewhere.

Here, we compared the species assemblages of Neotropical Nymphalidae found in naturally occurring treefall gaps with paired undisturbed understory sites. We hypothesized that different species assemblages would occur in treefall gaps compared to the undisturbed understory and that the differences would increase with increasing gap size. Furthermore, we 
quantified the effect of sun exposure, vegetation structure, and the number of flowering and fruiting plants on the butterfly assemblages between gap and understory habitats.

\section{METHODS}

StUdy AREA.-The study was conducted in southeastern Peru, at the Cocha Cashu Biological Station (EBCC) located within the Manu National Park (1 $\left.1^{\circ} 51^{\prime} 23^{\prime \prime} \mathrm{S} 71^{\circ} 43^{\prime} 17^{\prime \prime} \mathrm{W}\right)$. With over two million hectare, Manu is one of few remaining pristine regions with an undisturbed but diverse biota. The average annual rainfall is about $2300 \mathrm{~mm}$ and a mean annual temperature of

around $24^{\circ} \mathrm{C}$. EBCC encompasses over $16 \mathrm{~km}^{2}$ of lowland rain forest, served by around $60 \mathrm{~km}$ of trails.

SAMPLING DESIGN AND MEASUREMENT OF VARIABLES.-We randomly selected 15 treefall gaps, 5-10 yr old, ranging in area from approximately $100 \mathrm{~m}^{2}$ to $1000 \mathrm{~m}^{2}$. Gap areas were estimated following Brokaw’s (1982) method. To reduce potential spatial autocorrelation, all gaps were separated by at least $100 \mathrm{~m}$ (the maximum distance was over $3 \mathrm{~km}$ ). For each treefall gap one paired undisturbed understory control site was chosen by selecting a random compass direction and distance (between $50 \mathrm{~m}$ to $200 \mathrm{~m}$ ) from the center of each gap (Fig. S1). If a control site overlapped with a treefall gap, a new random direction was chosen.

We used an incident light meter (Mastech, LX 1010B digital lux meter) to quantify the amount of incoming sunlight in gaps and understory controls. During days without cloud cover, we measured the sunlight at five locations (three along the length and two along the width) within each habitat, between 1100 to $1400 \mathrm{~h}$ and the mean sunlight were calculated and used in subsequent analyses. 
For each gap and their understory control we randomly selected ten $1 \mathrm{~m}^{2}$ plots and recorded the number, height, and diameter of all vines, herbaceous, and woody plants. In addition, we weekly quantified the number of flowering and fruiting plants in ten randomly selected $1 \mathrm{~m}^{2}$ plots within all gaps and understories. All plants were identified to family level.

BUTTERFLY TRAPPING.-Butterflies were caught in traps consisting of a $65 \mathrm{~cm}$ long cylinder of black nylon mesh with a diameter of 30 cm (DeVries 1987; Sutherland 2006). A 35 cm plastic plate was attached $3 \mathrm{~cm}$ below the cylinder and used for baiting. Because gaps were elliptic in shape, two traps were placed equally spaced along the major axis, at one third and two thirds of its length. Thus a total of 60 traps, two traps within each treefall gap and two in understory controls were used. The traps were attached to branches, approximately $2 \mathrm{~m}$ above the ground level. The trapping period started at the beginning of July and ended in October 2009, covering 13 weeks, with five consecutive trapping days per week resulting in a total of 1950 trap days. Each trap was baited with one ripe banana and some drops of vanilla extract. The bait was enclosed within a metal mesh to reduce consumption by other species while still allowing free access for the butterfly’s proboscis. Each trap was re-baited every second day, and the old bait was left in the trap to ensure a mixture of ripe to over-ripe bait. All captured butterflies were photographed and individually marked by writing a number on the wing. Individuals were identified to species, following the nomenclature and classification of Lamas (2004). Photographs and voucher specimens were also sent to specialists for identification and species verifications. Of a total of 1531 trapped individuals, 2.7 percent remained unidentified (primarily because they either escaped during handling, or had damaged wings) and were excluded from statistical analyses. Morphology on all captured butterflies was measured: body length, forewing 
breadth (minimum distance between tornus and costa) and length, abdomen width and length, thorax width and length, all accurate to $1 \mathrm{~mm}$. Thorax volume was calculated as length $\times$ width $^{2}$. The distribution for each species was estimated in four classes from widespread in the Neotropical region to restricted to a single or a few countries based on Neild $(1996,2008)$.

STATISTICAL ANALYSES.—Species accumulation curves based on gap and understory traps were compiled using EstimateS v. 7.51 (Colwell 2011) and the MaoTau index (the number of species observed) per habitat. Species accumulation curves were also calculated by weeks to estimate potential effects of seasonality. Differences in species number and number of individuals (square-root transformed) was assessed in a mixed-model ANOVA using STATISTICA 12 (Statsoft Inc.), after merging data from the two traps per gap and corresponding understory. Hence, each gap contributed one data point, and gap/understory pair identity was used as a random factor.

Differences in species assemblages between gap and understory habitats, among gaps and individual species associations to environmental variables and habitats were analyzed by ordination using the CANOCO 4.5 software and Principal Component Analysis (PCA) (ter Braak \& Smilauer 2002). The first PCA compared the butterfly species assemblages between gap and understory habitats and were used to display the individual species associations with vegetation structure (density, height, and diameter of vines, herbaceous and woody plants), number of flowering and fruiting plants from different families and light availability. All species data were transformed $(\log 10(\mathrm{x}+1))$ in order to minimize the impact of a few very abundant species. Variables describing vegetation structure, flowering and fruiting plants and light were 
passive variables in the analysis. The second PCA was conducted using only data from the gaps, involving the same variables but also including gap size as a passive variable.

We hypothesized that the species composition of understory and gap would become increasingly different with increasing gap size. We tested this by calculating $\chi^{2}$-distances, within each pair gap-understory pair, based on number of individuals from different species. A linear

regression then related $\chi^{2}$-distances to gap size. The $\chi^{2}$-distances were based on transformed species data and gap sizes were square-root transformed.

To further explore the degree of species’ association with gap versus understory habitats, a partial redundancy analysis (pRDA) was conducted. This involved gap/understory as the only (categorical) environmental variable and gap-understory -pair identity as a number of categorical covariables (thereby eliminating some of the spatial variation in the data). The statistical significance of the model was assessed in a Monte Carlo permutation test (9999 permutations). To further interpret the results, data on host plant associations were collected from DeVries (1987), Beccaloni et al. (2008) and Robinson et al. (2012) to identify possible mechanisms causing the patterns among butterfly assemblages.

\section{RESULTS}

ButTERFLy ASSEMBLAGES IN GAPS AND UNDERSTORY.- A total of 1531 individuals belonging to 82 Nymphalid species were captured (42 individuals could not be identified). Of these, 775 were captured in the understory and 756 in gaps. We trapped significantly $\left(F_{1,14}=14.42 ; P=0.00196\right)$ higher mean number of species in gaps $(10.0 \pm 4.1 \mathrm{SD}$, range $5-22)$ than in the corresponding understory sites $\left(7.0 \pm 2.9\right.$, range $3-13$; Fig. S2). There was no difference $\left(F_{1,14}=0.018\right.$; 
$P=0.894$ ), however, in mean number of individuals in the gaps (26.4 \pm 13.3 , range 7-65) compared to the understory (26.9 \pm 13.6 , range 11-57). Panacea prola was the most occurring species, representing 60.7 percent of the total number of individuals, both in gaps (52.3\%) and understory habitats (68.9\%). Overall, 71 species were found in gaps and 50 species in the understory (Fig. 1A). The time-based accumulation curves showed a relatively steep increase in number of species with time (Fig. 1B).

In general, there were larger between-site differences of butterfly assemblages in gaps than between assemblages in the understory (Fig. 2). Furthermore, the dissimilarity in butterfly assemblages compared to understory controls increased with gap size (Fig. 3).

PCA analyses across habitats and vegetation variables indicated that species associations were strongest affected by gap and understory habitats as indicated by the position of the centroids (Fig. 4A). If gap versus understory had been the overall dominating factor, their centroids should have been positioned along the first axis. The fact that this was not the case indicated that other factors were also important, most notably vine and herb densities, with arrows pointing perpendicular to gap and understory centroids (Fig. 4B). Light level was also a contributing factor but, as expected, it was highly associated with gaps. Overall, there were no clear associations of butterfly assemblages with most of the flowering and fruiting plant families (Fig 4C). Butterflies primarily encountered in the understory, for instance, Tigridia acesta and Nessaea obrinius, however, were associated with Malvaceae and Violaceae, whereas gap species such as Zaretis isidora and Pyrrhogyra amphiro showed a high association with Annonaceae. Taygetis angulosa was associated with several vines belonging to Siparunaceae and Verbenaceae (Fig. 4C). 
The pRDA, performed to investigate the degree of species' association within gaps versus understory (after accounting for spatial patterns), indicated that the group associated with the understory contained relatively few species, including T. acesta, Catoblepia berecynthia, $C$. xanthus, and $N$. obrinius (Table 1, Table S1). The gap associated species were more numerous with Pyrrhogyra crameri, Temenis laothoe, Archeoprepona demophon and Morpho helenor, as the most distinct ones (Table 1, Table S1). We could also distinguish non-specialists, those with pRDA scores close to zero, e.g., Pseudobedis valentina. There were a significant negative correlation between pRDA scores and wing area to thoracic volume ratio and abdomen length i.e., species associated with understory had significantly higher wing area to thoracic volume (Table 2). There were no significant differences in pRDA scores between species with regard to distribution classes (one-way ANOVA: $F_{3,77}=1.014, P=0.39$ ).

COMPARISON OF BUTTERFLY ASSEMBLAGES AMONG GAPS. - When considering assemblages only in gaps, there were clear patterns of associations with vegetation structure (Fig. 5). The majority of the species avoided gaps with high vine densities, and were associated with higher light levels and a high density of plants other than vines. Only few species such as Taygetis angulosa, $T$. sosis, and T. laches, were associated with high vine density. Interestingly, several species, including Nessaea obrinius and Pyrrhogyra crameri, were associated with small gaps, whereas Zaretis isidora, Adelpha jordani, and Memphis glauce were associated with large gaps and a high amount of sunlight. There were no overall associations of butterfly assemblages with flowering and fruiting plant families in gaps (Fig. 5C). Most butterfly species, however, except Taygetis spp., avoided vines belonging to Siparunaceae, Verbenacea, and Sapindaceae. Pyrrhogyra crameri, Panacea prola, and $P$. regina were associated with woody plants of the 
family Solanaceae. Many butterfly species, e.g., A. jordani, Temenis laothoe, and M. glauce, were associated with Costaceae and Annonaceae.

\section{DISCUSSION}

BUTTERFLY ASSEMBLAGES IN GAPS AND UNDERSTORY.-Our results support the hypothesis that natural disturbances can increase butterfly species diversity. Treefalls create gaps of varying size and vegetation structure which are utilized by different butterfly assemblages of fruit-feeding nymphalids than in the understory habitat. Some species showed strong associations with gaps (i.e., Pyrrhogyra amphiro and Temenis laothoe) whereas other species clearly preferred the undisturbed understory (i.e., Tigridia acesta and Nessaea obrinius). Whether this pattern holds for other butterfly groups or families remains to be established, as this study focuses only on fruit-feeding nymphalids.

The species associated with understory in this study had significantly higher wing area to thoracic volume and longer abdomens. Field observations by Hall and Willmott (2000) suggest that species with high wing area to thoracic volume often tend to be slow flying, with relatively low wing beat frequencies. Other studies have shown that species associated with rain forest canopy and gaps have a morphology indicating faster flight (Hill et al. 2001, DeVries et al. 2010) than species living in the understory. The reason for the differences between the species groups might be that species living in gaps utilize a habitat with high temperatures enabling fast flight (Hall \& Willmott 2000) with a higher predation pressure. Chai and Srygley (1990) showed that butterflies with smaller wing areas and shorter and stouter bodies had a faster and more irregular flight and escape more frequently from predator attacks than butterflies with slender bodies and larger wing areas. Gap species has been shown to have better dispersal ability (Hill et 
al. 2001) and that might be another reason for the morphology differences as gaps are a temporary habitat. Of the 82 species captured, 39 percent were only found in gaps, whereas 13 percent were restricted to the understory. Levey (1988) reported similar results from a Costa Rican wet forest where 40 percent of the birds species were found significantly more often in the gaps than in understory. Only 5 percent of the birds were found more often in the understory. Studies on insects reported mixed results. For example, a higher number of butterfly species in gaps were found in a Vietnamese montane rain forest (Spitzer et al. 1997), but in Bornean rain forests there was no difference in the number of species between gap and understory habitats (Hill \& Hamer 2004; Hamer et al. 2003). In a study that sampled diurnal insects in a Panamanian lowland forest, significant lower abundances (indicating lower species richness) for Formicidae, Coleoptera, and Psocoptera were found in gaps than understory sites (Shelly 1988). In contrast, Feener and Schupp (1998) found no effect on ant assemblages in treefall gaps compared to understory in a lowland forest in Panama.

The number of species increased quickly during the first sampling weeks, and leveled off as sampling progressed. The species accumulation curve did not reach an asymptote, indicating that more species would have been found with an increased sampling period. Many species are seasonal (DeVries et al. 1999, DeVries \& Walla 2001, Checa et al. 2009) and show a peak of abundance during a specific period only. For example, Panacea prola appeared first at week seven, and was the predominant species in both habitats (52\% of the individuals in gaps and 69\% in understory) from week 11 until the end of the study. A study covering ten years sampling in Ecuadorian Amazon showed that seasonal cycles of rainfall are the main drivers of seasonality of butterflies (Grøtan et al. 2012). 
Another point worth noting is that our traps were close to the ground level as the majority of the frugivorous species are likely to be found at ground level where fallen ripe fruits occur (Hill et al. 2001, Tangah et al. 2004). Nevertheless, vertical stratification of frugivorous Neotropical butterflies in intact forest has been previously noted (DeVries et al 1997, DeVries \& Walla 2001)and additional traps at the canopy level in our own study might have resulted in higher species richness.

COMPARISON OF BUTTERFLY ASSEMBLAGES AMONG GAPS.-As hypothesized, the dissimilarity in butterfly assemblages increased with gap size, with assemblages in small gaps being more similar to those in nearby undisturbed understory. Gap size has been shown to affect temperature and humidity (Fetcher et al. 1985), vegetation structure (Denslow 1987) and densities of fruiting plants (Levey 1988). Somewhat unexpectedly, however, butterfly assemblages also seemed to be affected by the amount of vines with most of the butterfly species displaying an avoidance to vines. Instead, many species were associated with the presence of woody plants in gaps (high numbers here representing regeneration of woody species). There were also higher light levels in gaps with a large amount of woody plants. The amount of light has been shown to be an important component of the structure of tropical forests, affecting butterfly assemblages (Sparrow et al. 1994). The amount of sunlight reaching the ground is also a critical factor for plant growth (Terborgh 1992), and thus might indirectly effect the quality of butterfly host plants (Blau 1980, Richards \& Coley 2008). The largest and most open gaps had the highest butterfly species diversity. Most vines are fast-growing species, covering gaps quickly, resulting in denser patches than woody plants. Thus the initial presence of vines might greatly influence the 
vegetation succession and development in gaps (Schnitzer et al. 2000) and hence their butterfly assemblages.

IMPORTANCE OF HETEROGENEITY.-Different nymphalid species were associated with gaps of different characteristics. For example, we encountered Pseudobedis valentina and Nessaea obrinius mainly in small shaded gaps while Adelpha jordani, Memphis glauce, Yphthimoides poltys, Temenis laothoe, Bia actorion, and Zaretis isidora occurred mainly in large open gaps. Several species of the genus Taygetis (T. angulosa, T. laches, and T. sosis), were found primarily in large gaps with dense vine cover. The association with different habitats and vegetation characteristics is probably due to the distribution of suitable host plants and adult resources. For example Temenis laothoe occur in the canopy but females use Sapindaceae vines at ground level in gaps as host plants and they frequently descend to the ground for fermenting fruits (Muyshondt 1973). The species most associated with gaps in our study, Pyrrhogyra crameri, is known to oviposit on Paullinea sp. (Sapindaceae) in tree fall gaps (DeVries 1987). The Taygetis spp. all use grasses as host plants (DeVries 1987) and grasses were mainly found in large gaps in our study. Their preference for vines may be due to their preference for shadier conditions even though they use grasses as host plants. The species associated with small gaps, Nessaea spp., use seedlings of Alchornea spp. (Euphorbiaceae) (DeVries 1987) that grow in gaps. The species most associated with the understory was Tigridia acesta, which use the pioneer species Cecropia spp. and Pourouma spp. as host plants. Basset et al. (2003), however, report that the larvae have only been collected from small and shaded saplings of understory host plants suggesting that the butterfly is an understory specialist. Three other species strongly associated with the understory were Catoblepia berecynthia, C. xanthus and Bia actorion. These are encountered in deep shade 
in the forest and all use palms as host plants, probably also in the shady understory. The butterflies classified as understory species in our study were also classified as understory species by DeVries and Walla (2001) in a study contrasting understory and canopy. Furthermore, several of the species associated with gaps in our study were classified as canopy species. It is likely that these species use both open gaps and canopy for feeding and for larval host plants.

Our results indicate considerable small-scale variation in butterfly species composition. Large differences in butterfly assemblages were found even between traps placed in the understory where variation in light and vegetation structure is limited. Similar variation between traps only 50-100 m apart has been found in central Brazil (Pinheiro \& Ortiz 1992) and in Borneo (Hill et al. 2001). The variation in butterfly assemblages among the gap traps was even greater than in the understory. To what extent this variation is due to the existence of critical resources in gaps of different sizes and vegetation structure or simply a result of canopy specialists infrequently descending to the ground remains to be elucidated.

Our results suggest that heterogeneity within a rain forest consisting of gaps at different successional stages within the undisturbed understory matrix, might be a critical factor in maintaining high butterfly species diversity. The availability of different habitats, following a gradient from an undisturbed understory matrix to large newly formed open gaps, to smaller and denser gaps, could be an important requirement for the coexistence of the species.

\section{ACKNOWLEDGMENTS}

Research permit to work in Manu National Park was kindly granted by the Peruvian government Institute of Natural Resources (INRENA). We thank Drs. Jacqueline Miller, Patrick Blandin, André Victor Lucci Freitas, and Gerardo Lamas for species identification. For excellent 
assistance in the field we thank Matias Perez Ojedadel Arco. We thank Andrew Neild for data on distribution. The authors wish to thank two anonymous referees whose comments have greatly improved this paper.

\section{SUPPORTING INFORMATION}

Additional Supporting Information may be found in the online version of this article.

TABLE S1. Ordination scores of Nymphalidae species sampled in traps and analyzed within a pRDA using habitat (gap vs. understory) as explanatory variable and the pairs of traps as covariables.

FIGURE S1. Spatial distribution of 15 gaps and their understory control sites, at Cocha Cashu Biological Station, within Manu National Park, Peru.

FIGURE S2. Number of species recorded in gaps and corresponding understory.

\section{LITERATURE CITED}

BASSet, Y., V. Novotny, S. E. MilLeR, AND R. L. Kitching. 2003. Conclusion: arthropods, canopies, and interpretable patterns. In Y. Basset, V. Novotny, S. E. Miller and R. L. Kitching (Eds). Arthropods of Tropical Forests. Spatio-Temporal Dynamics and Resource Use in the Canopy, pp. 394-405. Cambridge University Press, Cambridge. BeCCALONI, G. W., A. L., Viloria, S. K. HALL, AND G. S. Robinson. 2008. Catalogue of the Hostplants of the Neotropical Butterflies/ Catálogo de las Plantas Huésped de las 
Mariposas Neotropicales. m3m-Monografías Tercer Milenio, Volume 8. Zaragoza, Spain:

Sociedad Entomológica Aragonesa (SEA)/Red Iberoamericana de Biogeografía y

Entomología Sistemática (RIBES)/Ciencia y Tecnología para el Desarrollo

(CYTED)/Natural History Museum, London, U. K. (NHM)/Instituto Venezolano de

Investigaciones Científicas, Venezuela (IVIC).

BECK, H., M. S. GAINES, J. E. HinES, AND J. D. Nichols. 2004. Comparative dynamics of small mammal populations in treefall gaps and surrounding understorey within Amazonian rainforest. Oikos 106: 27-38.

BLAU, W. S. 1980. The effect of environmental disturbance on a tropical butterfly population. Ecology 61:1005-1012.

BROKAW, N. V. L. 1982. Treefalls: frequency, timing, and consequences. In E. G. LEIGH, A. S. RAND AND D. M. WINDSOR (Eds.). pp. 101-108. The ecology of a tropical rainforest, Seasonal rhythms and long-term changes, Smithsonian Institute, Washington DC.

Chai, P. AND R.B SRYgLey. 1990. Predation and the flight, morphology, and temperature of neotropical rain-forest butterflies. Am. Nat. 135: 748-765.

Checa, M. F., A. Barragan, J. Rodriguez, And M. Christman. 2009. Temporal abundance patterns of butterfly communities (Lepidoptera: Nymphalidae), in the Ecuadorian Amazonia and their relationship with climate. Ann. Soc. Entomol. Fr., 45: 470-486.

Cleary, D. F. R., M. J. Genner, , L. P. Koh, T. J. B Boyle, T. Setyawati, R. De Jong, and S. B. J. MENKEn. 2009. Butterfly species and traits associated with selectively logged forest in Borneo. Basic Appl. Ecol. 10: 237-245.

COLWELL, R. 2011. EstimateS: Statistical estimation of species richness and shared species from samples. Version 8.2. http://viceroy.eeb.uconn.edu/EstimateS 
ConNelL, J. H. 1978. Diversity in tropical rain forests and coral reefs. Science 199: 1302-1310.

Denslow, J. S. 1980. Gap partitioning among tropical rain forest trees. Biotropica (Supplement) 12: 47-55.

Denslow, J. S. 1987. Tropical rainforest gaps and tree species diversity. Annu. Rev. Ecol. Syst. 18: 431-451.

Denslow, J. S., T. C. Moermond, And D. J. LeVey. 1986. Spatial components of fruit display in understory trees and shrubs. In A. EsTRADA AND T. H. FLEMING (Eds). Frugivores and seed dispersal. pp. 37-44. W, Junk Publisher, Dordrecht, The Netherlands.

DEVRIES, P. J. 1987. The butterflies of Costa Rica and their natural history, vol 1. Papilionidae, Pieridae and Nymphalidae, Princeton University Press, Princeton, New Jersey.

DeVRIES, P. J., D. MurRAY, AND R. LANDE. 1997. Species diversity in vertical, horizontal, and temporal dimensions of a fruit-feeding butterfly community in an Ecuadorian rainforest. Biol. J. Linn. Soc. 62: 343-364.

DEVRIES, P. J. AND T. R. WALlA. 2001. Species diversity in spatial and temporal dimensions of fruit-feeding butterflies from two Ecuadorian rainforests. Biol. J. Linn. Soc. 74: 1-15.

DeVries, P. J., C. M. PenZ, AND R. Hill. 2010. Vertical distribution, flight behavior, and evolution of wing morphology in Morpho butterflies. J. Anim. Ecol. 79: 1077-1085.

FEENER, D. H., AND E. W. SCHUPP. 1998. Effect of treefall gaps on the patchiness and species richness of Neotropical ant assemblages. Oecologia 116: 191-201.

Fermon, H., M. WALtert, R. I. VAne-Wright, And M. MuhlenBerg. 2005. Forest use and vertical stratification in fruit-feeding butterflies of Sulawesi, Indonesia: impacts for conservation. Biodiversity Conserv. 14: 333-350. 
Grøtan, V., R. LAnde, S. Engen, B.-E. SAether, And P. J. DeVRies. 2012. Seasonal cycles of species diversity and similarity in a tropical butterfly community. J. Anim. Ecol. 81: 714723.

Hamer K. C., J. K. Hill, S.Benedick, N. Mustaffa, T. N. Sherratt, M. Maryatis, ANd V. K. CHEY. 2003. Ecology of butterflies in natural and selectively logged forests of northern Borneo: the importance of habitat heterogeneity. J. Appl. Ecol. 40: 150-162.

Hamer, K. C., J. K. Hill, S. Benedick, N. Mustaffa, V. K. Chey, And M. Mohamed. 2006. Diversity and ecology of carrion and fruit-feeding butterflies in Bornean rainforest. J. Trop. Ecol. 22: 25-33.

HARTSHORN, G. S. 1978. Treefalls and tropical forest dynAmics. In P. B. TOMLINSON AND M. H. Zimmermann (Eds.). Tropical trees as living systems. pp. 617-638. Cambridge University Press, London, UK.

HALL, J. P. W. AND K. R. WILLMOTT. 2000. Patterns of feeding behaviour in adult male riodinid butterflies and their relationship to morphology and ecology. Biol. J. Linnean Soc. 69: 123

HiLl, J. K., K. C. HAMER, J. TANGAH, AND M. DAWOOD. 2001. Ecology of tropical butterflies in rainforest gaps. Oecologia 128: 294-302.

HILL, J. K., AND K. C. HAMER. 2004. Determining impacts of habitat modification on diversity of tropical forest fauna: the importance of spatial scale. J. Appl. Ecol. 41: 744-754.

Houter, N. C., AND T. L. Pons. 2005. Gap size effects on photoinhibition in understorey saplings in tropical rainforest. Plant Ecology 179: 43-51.

LAMAS, G. 2004. Atlas of Neotropical Lepidoptera, Checklist: Part 4A, HesperioideaPapilionoidea, Scientific Publishers, Florida. 
Leigh, E. G., P. Davidar, C. W. Dick, J. P. Puyravaud, J. Terborgh, H. Ter Steege, and S. J. WRIGHT. 2004. Why do some tropical forests have so many species of trees? Biotropica 36: 447-473.

LEVEY, D. J. 1988. Tropical wet forest treefall gaps and distributions of understory birds and plants. Ecology 69: 1076-1089.

Molino, J. F., AND D. SABATIER. 2001. Tree diversity in tropical rain forests: a validation of the intermediate disturbance hypothesis. Science 294: 1702-1704.

MuYshONDT, A. 1973. Notes on the life cycle and natural history of butterflies of El Salvador. III A.-Temenis laothoe liberia (Nymphalidae-Catonephelinae). Journal of the New York Entomological Society. 81: 224-233.

Neild, A. F. E. 1996. The Butterflies of Venezuela. Part 1: Nymphalidae I (Limenitidinae, Apaturinae, Charaxinae). A comprehensive guide to the identification of adult Nymphalidae, Papilionidae and Pieridae. Meridian Publications, London, UK.

Neild, A. F. E, 2008. The Butterflies of Venezuela, Part 2: Nymphalidae II (Acraeinae, Libytheinae, Nymphalinae, Ithomiinae, Morphinae). Meridian Publications, London, UK.

Richards, L. A., AND P. D. COLEY. 2008. Combined effects of host plant quality and predation on a tropical Lepidopteran: a comparison between treefall gaps and the understory in Panama. Biotropica 40: 736-741.

PeArson T. R. H., D. F. R. P. Burslem, R.E. Goeriz, AND J. W. DALLING. 2003. Interactions of gap size and herbivory on establishment, growth and survival of three species of neotropical pioneer trees. J Ecol 91:785-796.

Pinheiro C. E., AND J. V. ORTIZ. 1992. Communities of fruit-feeding butterflies along a vegetation gradient in central Brazil. J. Biogeogr. 19: 505-511. 
Robinson G. S., P. R. ACKeRY, I. J. KitChing, G. W. BeCCAlONi AND L. M. HeRnández. 2012. HOSTS - A Database of the World's Lepidopteran Hostplants. Natural History Museum, London. http://www.nhm.ac.uk/hosts. (Accessed: 11 Sep.2012).

SCHNITZER, S., AND W. P. CARSON. 2001. Treefall gaps and the maintenance of species diversity in a tropical forest. Ecology 82: 913-919.

SCHNITZER, S. A., AND F. BONGERs. 2002. The ecology of lianas and their role in forests, Trends Ecol. Evol. 17: 223-230.

SHELLY, T. E. 1988. Relative abundance of day-flying insects in treefall gaps vs. shaded understory in a Neotropical forest. Biotropica 20: 114-119.

Sparrow, H., T. SISK, P. EHRLICH, AND D. MurPhy. 1994. Techniques and guidelines for monitoring neotropical butterflies. Conserv. Biol. 8: 800-809.

SPITZER, K., J. JAROS, J. HAVELKA, AND J. LEPS. 1997. Effect of small-scale disturbance on butterfly communities of an Indochinese montane rainforest. Conserv. Biol. 80: 9-15.

SutheRLAND, W. J. 2006. Ecological Census Techniques: a handbook. Cambridge University Press, Cambridge, UK.

TANGAH, J., J. K. Hill, K. C. HAMER, AND M. M. DAWOOD. 2004. Vertical distribution of fruitfeeding butterflies in Sabah, Borneo. Sepilok Bulletin 1: 17-27.

TER BRAAK, C. J. F., AND P. SMILAUeR. 2002. Canoco 4 Microcomputer power, Ithaca, NY, USA.

Terborgh, J. 1992. Diversity and the tropical rain forest. Scientific American Library, New York, New York. 
WhitMore, T. C. 1978. Gaps in the forest canopy. In P. B. TOMLinson AND M. H. ZimmermanN (Eds.). Tropical trees as living systems. pp. 639-655. Cambridge University Press, London, UK. 
TABLE 1. Results from a pRDA with habitat (gap vs. understory) as an explanatory variable and the pairs of traps as covariable. Only the twelve species with the highest scores and more than five individuals are shown here. P-value for the model was 0.0001 (Monte-Carlo permutation tests with 9999 permutations, Trace $=0.048)$.

\begin{tabular}{lccc} 
& RDA & Frequency of & Frequency of \\
& scores & $\begin{array}{c}\text { individuals in } \\
\text { understory }\end{array}$ & $\begin{array}{c}\text { individuals in } \\
\text { gaps }\end{array}$ \\
\hline Tigridia acesta & -0.4347 & 15 & 1 \\
Catoblepia berecynthia & -0.3386 & 14 & 4 \\
Catoblepia xanthus & -0.2737 & 12 & 3 \\
Bia actorion & -0.2596 & 6 & 1 \\
Panacea prola & -0.2102 & 555 & 414 \\
Nessaea obrinus & -0.1717 & 29 & 19 \\
Adelpha iphiclus & 0.3025 & 1 & 10 \\
Zaretis isidora & 0.3239 & 0 & 8 \\
Morpho helenor & 0.3442 & 2 & 13 \\
Temenis laothoe & 0.3537 & 2 & 16 \\
Pyrrhogyra amphiro & 0.3563 & 0 & 8 \\
Pyrrhogyra crameri & 0.3912 & 2 & 18
\end{tabular}


TABLE 2. Correlation coefficients between species $(\mathrm{N}=81)$ pRDA scores and morphological variables.

\begin{tabular}{llll}
\hline Morphological variable & Transformation & $\mathrm{R}$ & $\mathrm{P}$ \\
\hline Body length & & -0.165 & 0.142 \\
Forewing breadth & -0.0298 & 0.792 \\
Forewing length & -0.0454 & 0.687 \\
Abdomen width & Square-root & -0.0571 & 0.612 \\
Abdomen length & & -0.320 & 0.00360 \\
Thorax width & & +0.123 & 0.275 \\
Thorax length & & +0.0733 & 0.515 \\
Thorax volume (TV) & Logarithmic & +0.129 & 0.253 \\
Wing area (WA) & Logarithmic & -0.0452 & 0.689 \\
Wing shape & & -0.0341 & 0.763 \\
WA/TV & Logarithmic & -0.269 & 0.0154 \\
\hline
\end{tabular}




\section{Figure legends}
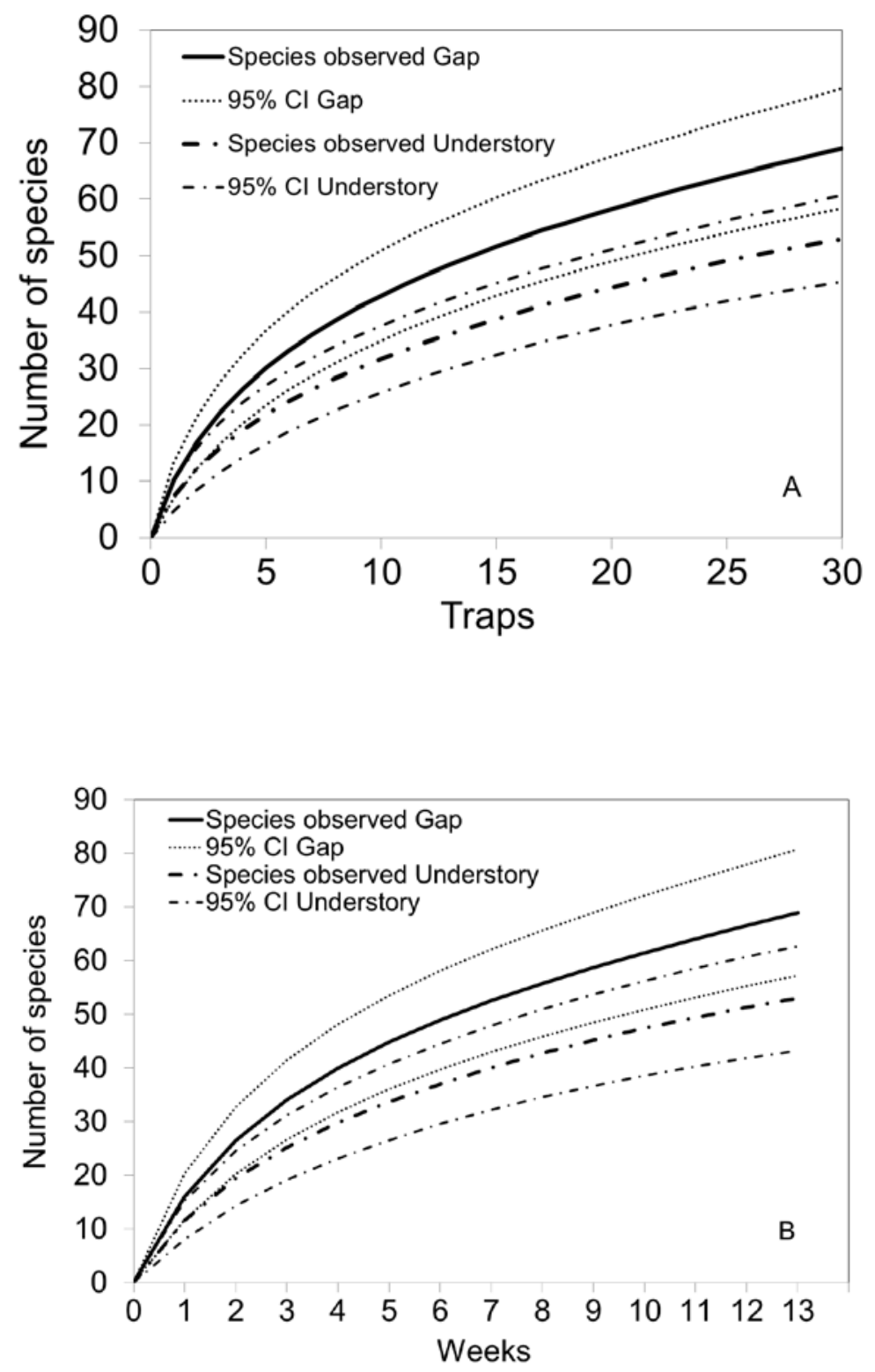

FIGURE 1. Butterfly species accumulation curves by traps (A) in a total of 30 traps, and by weeks (B) during 13 weeks, in gap and understory habitats. Each curve is presented with a 95\% confidence interval. See Table S1 for species names. 

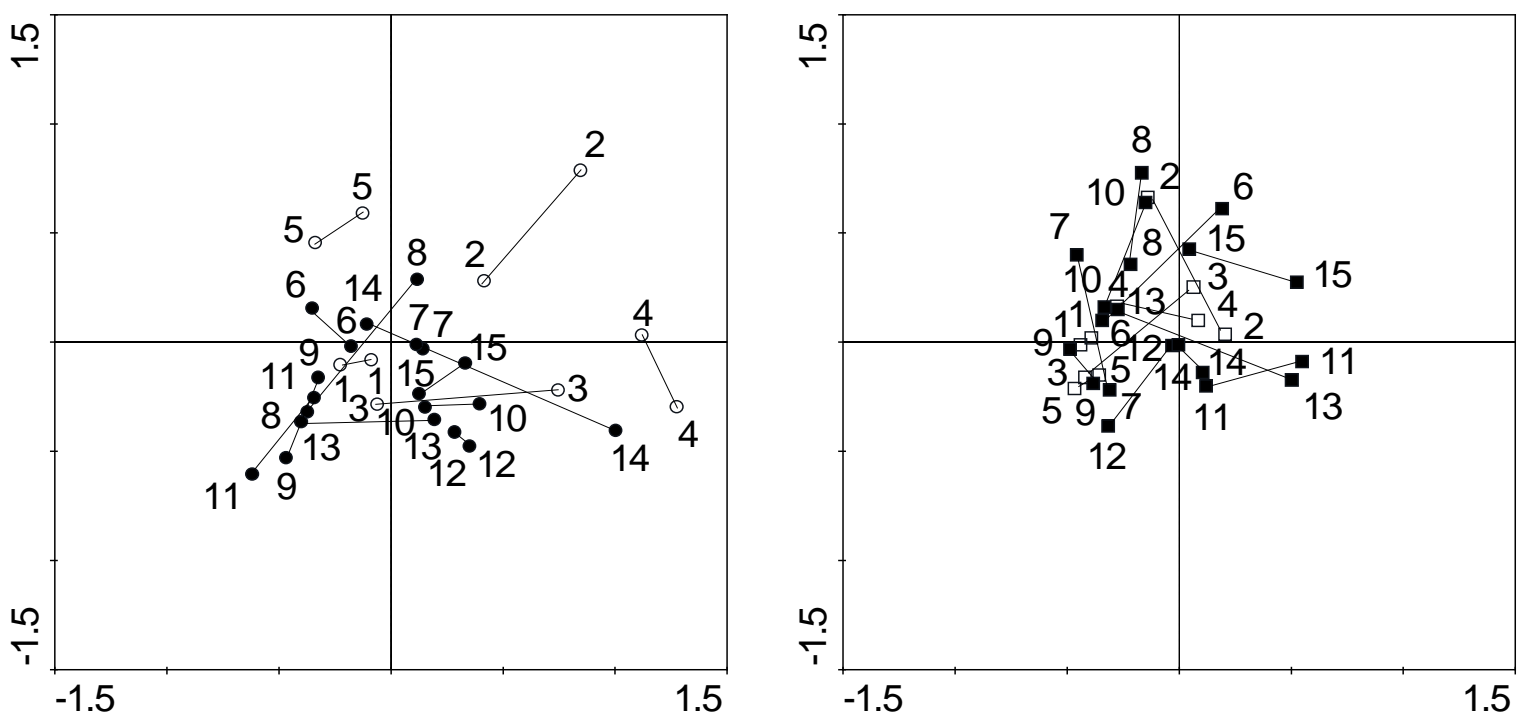

FIGURE 2. PCA ordination diagram of butterfly assemblages from traps in gaps (A), divided in small $\left(<300 \mathrm{~m}^{2}\right)$ and large gaps $\left(>300 \mathrm{~m}^{2}\right)$, and understory (B). Lines link the two traps at a site. Eigenvalues of PC1 and PC2 were 17.5 and 10.7. 


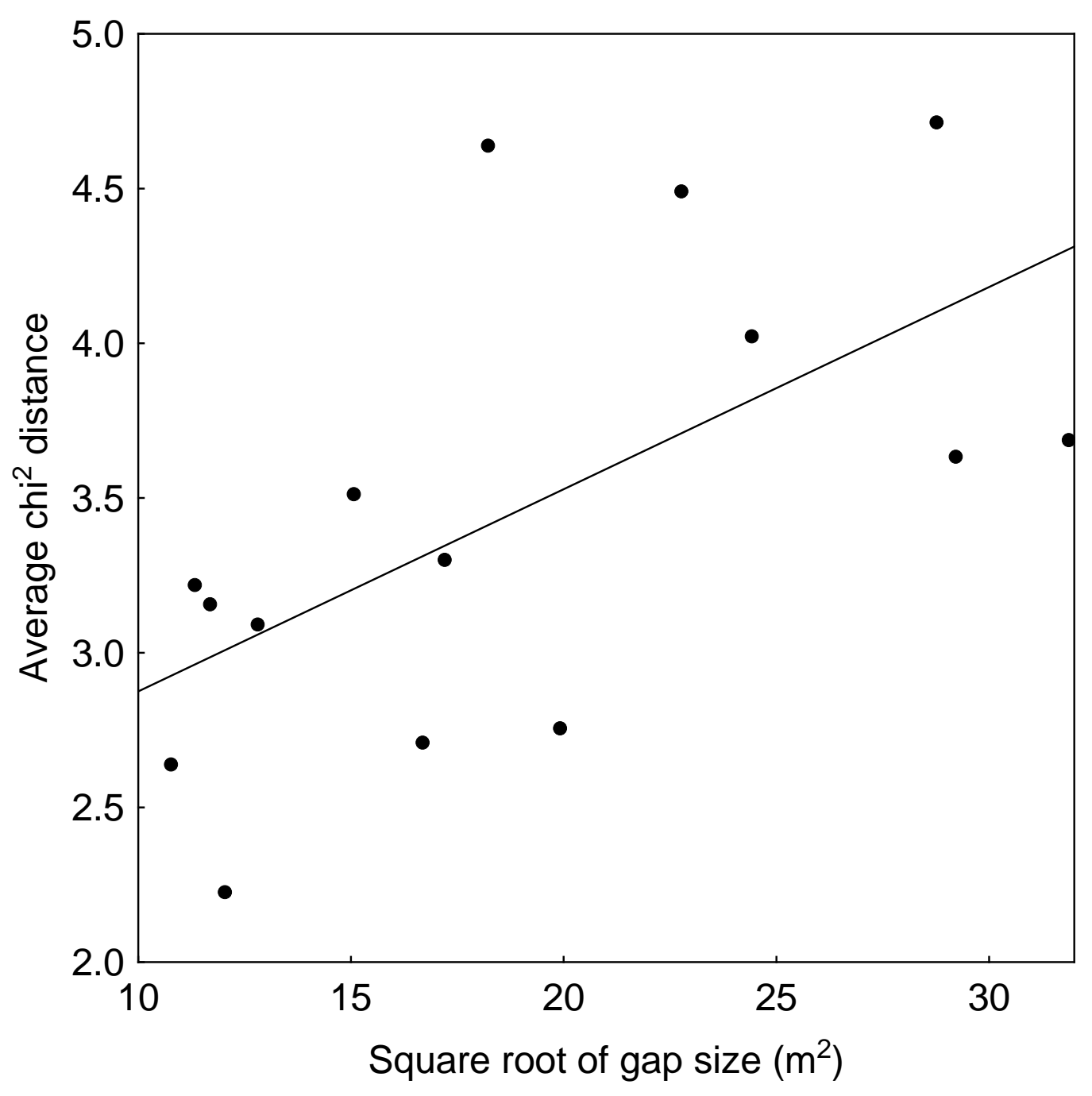

FIGURE 3. Dissimilarity ( $\chi^{2}$-distances) between butterfly assemblages of Nymphalidae in pairs of gap and understory traps as a function of gap size. $\chi^{2}$-distances were calculated for the gap trap and understory trap that were located closest to each other, then averaged per gap. ( $y=2.22$ $\left.+0.0653 x ; r=0.61, P=0.0153 ; R^{2}=0.37\right)$. 

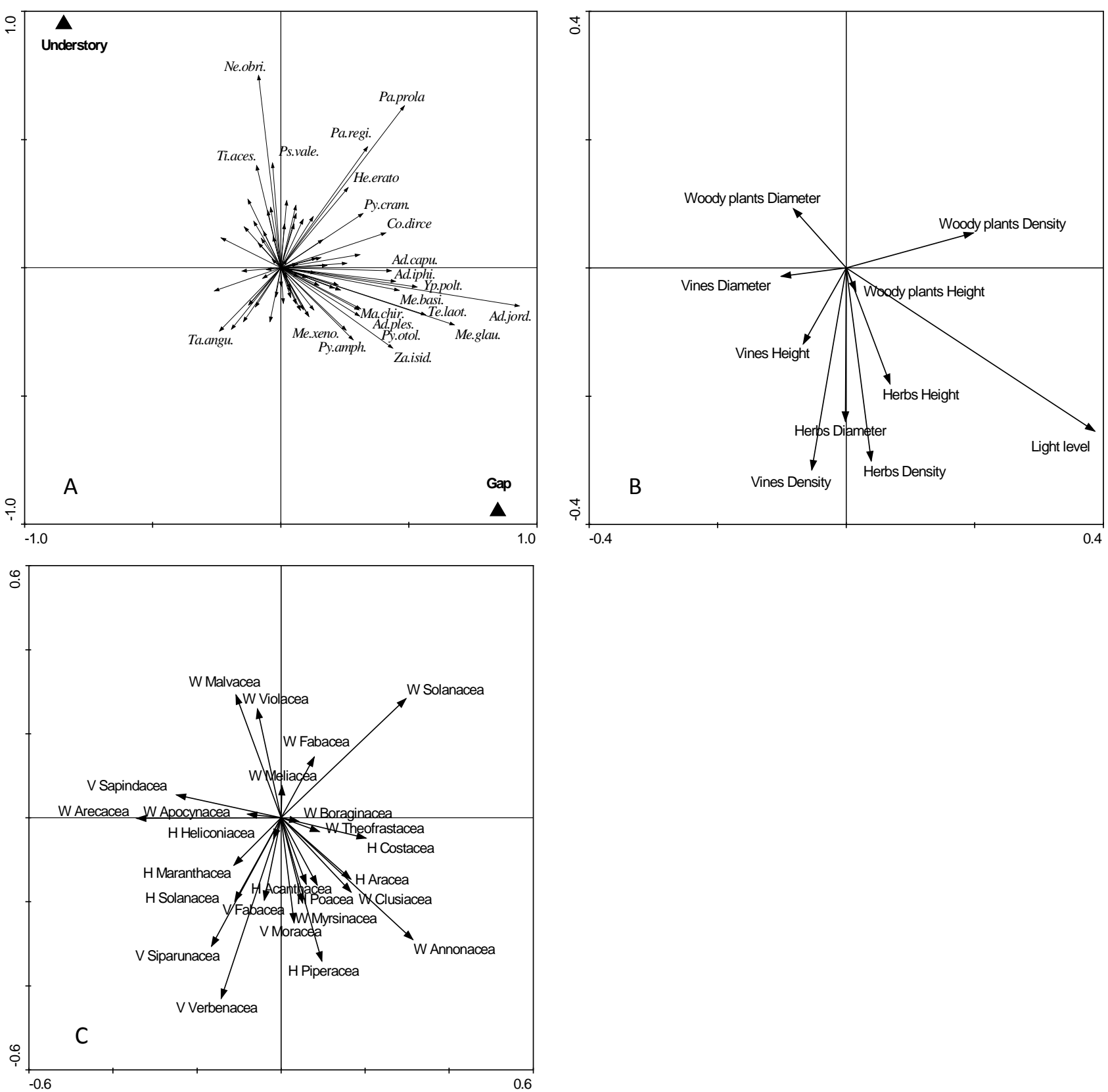

FIGURE 4. PCA ordination diagram of butterfly assemblages (A), environmental variables (B) and flowering and fruiting plant families (C). Only the 22 butterfly species that contribute most to the model are shown with species names. Eigenvalues of PC1 and PC2 were 17.5 and 10.7. 

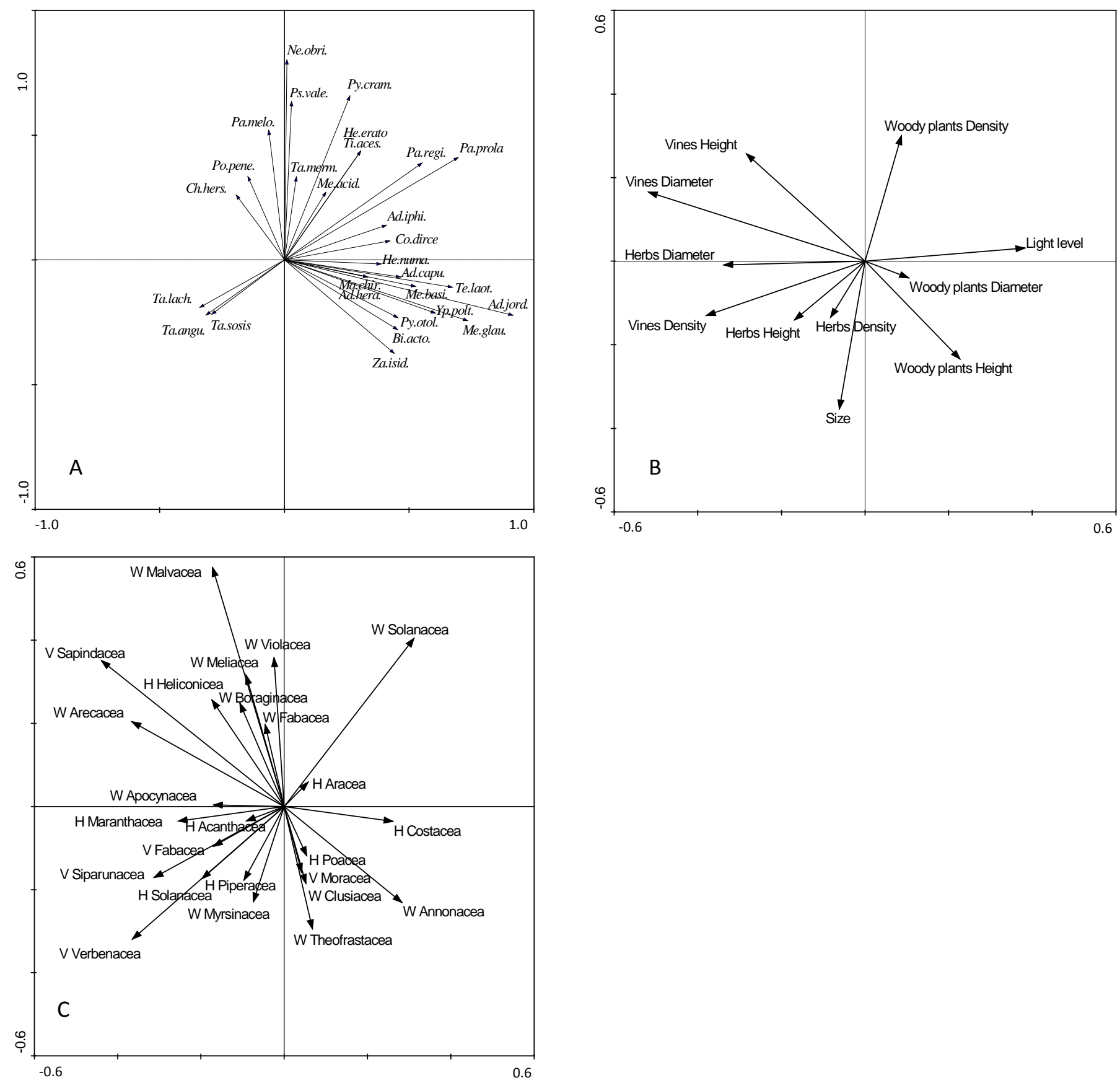

FIGURE 5. PCA ordination diagram of butterfly communities (A) environmental variables (B) and nectar and fruiting plant families (C) in 15 treefall gaps in Manu National Park, Peru. Only the 29 species that contribute most to the model are shown. Eigenvalues of PC1 (x axis) and PC2 (y axis) were 22.0 and 11.3. 
TABLE S1. Ordination scores of Nymphalidae species sampled in traps and analyzed within a pRDA using habitat (gap vs. understory) as explanatory variable and the pairs of traps as covariables. The order of the species indicates their habitat preferences, starting from the species mostly associated with the understory to the species mostly associated with gaps. P-value for the model was 0.0001 (Monte-Carlo permutation tests with 9999 permutations, Trace $=0.048$ ). Negative and positive pRDA value means association with understory and gap, respectively. Data on host plants associations were collected from DeVries (1987); Beccaloni et al. (2008) and Robinson et al. (2012). A question mark after the host plant family means that species-wise information are lacking but that the suggested host plant family is probable, due to general knowledge about the group or related species.

\begin{tabular}{|c|c|c|c|c|c|c|c|c|c|c|}
\hline \multirow[t]{2}{*}{ Habitat } & \multirow[t]{2}{*}{ Species } & \multirow[t]{2}{*}{ RDA } & \multicolumn{3}{|c|}{ Understory } & \multicolumn{3}{|c|}{ Gap } & \multirow[t]{2}{*}{ Host plant } & \multirow[t]{2}{*}{ Host plant family } \\
\hline & & & Frequency & No. of ind. & Trap records & Frequency & No. of ind. & Trap records & & \\
\hline \multirow{11}{*}{ 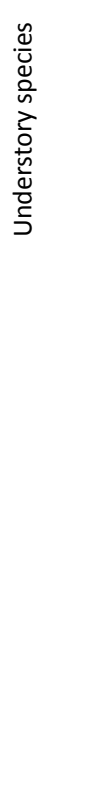 } & Tigridia acesta & -0.4347 & 15 & 15 & 12 & 1 & 1 & 1 & $\begin{array}{l}\text { Cecropia sp., Pourouma } \\
\text { bicolor, Coussapoa } \\
\text { nymphaeifolia, Ficus sp., } \\
\text { Theobroma sp. }\end{array}$ & $\begin{array}{l}\text { Urticaceae, } \\
\text { Moracea, } \\
\text { Sterculiaceae }\end{array}$ \\
\hline & Catoblepia berecynthia & -0.3386 & 14 & 11 & 13 & 4 & 4 & 4 & & Arecaceae \\
\hline & Catoblepia xanthus & -0.2737 & 12 & 12 & 9 & 3 & 3 & 3 & & Arecaceae \\
\hline & Bia actorion & -0.2596 & 6 & 6 & 6 & 1 & 1 & 1 & & Arecaceae \\
\hline & Panacea prola & -0.2102 & 555 & 554 & 30 & 414 & 400 & 30 & Caryodendron orinicense & Euphorbiaceae \\
\hline & Hamadryas arinome & -0.1857 & 2 & 2 & 2 & 0 & 0 & 0 & Dalechampia sp. & Euphorbiaceae \\
\hline & Manataria hercyna & -0.1857 & 2 & 2 & 2 & 0 & 0 & 0 & Bambusa sp. & Poaceae \\
\hline & Nessaea obrinus & -0.1717 & 29 & 16 & 16 & 19 & 15 & 11 & Alchornea sp. & Euphorbiaceae \\
\hline & Chloreuptychia herseis & -0.1558 & 5 & 4 & 5 & 2 & 2 & 2 & & Poaceae \\
\hline & Amphidecta calliomma & -0.1302 & 1 & 1 & 1 & 0 & 0 & 0 & & Poaceae? \\
\hline & Amphidecta pignerator & -0.1302 & 1 & 1 & 1 & 0 & 0 & 0 & & Poaceae? \\
\hline
\end{tabular}




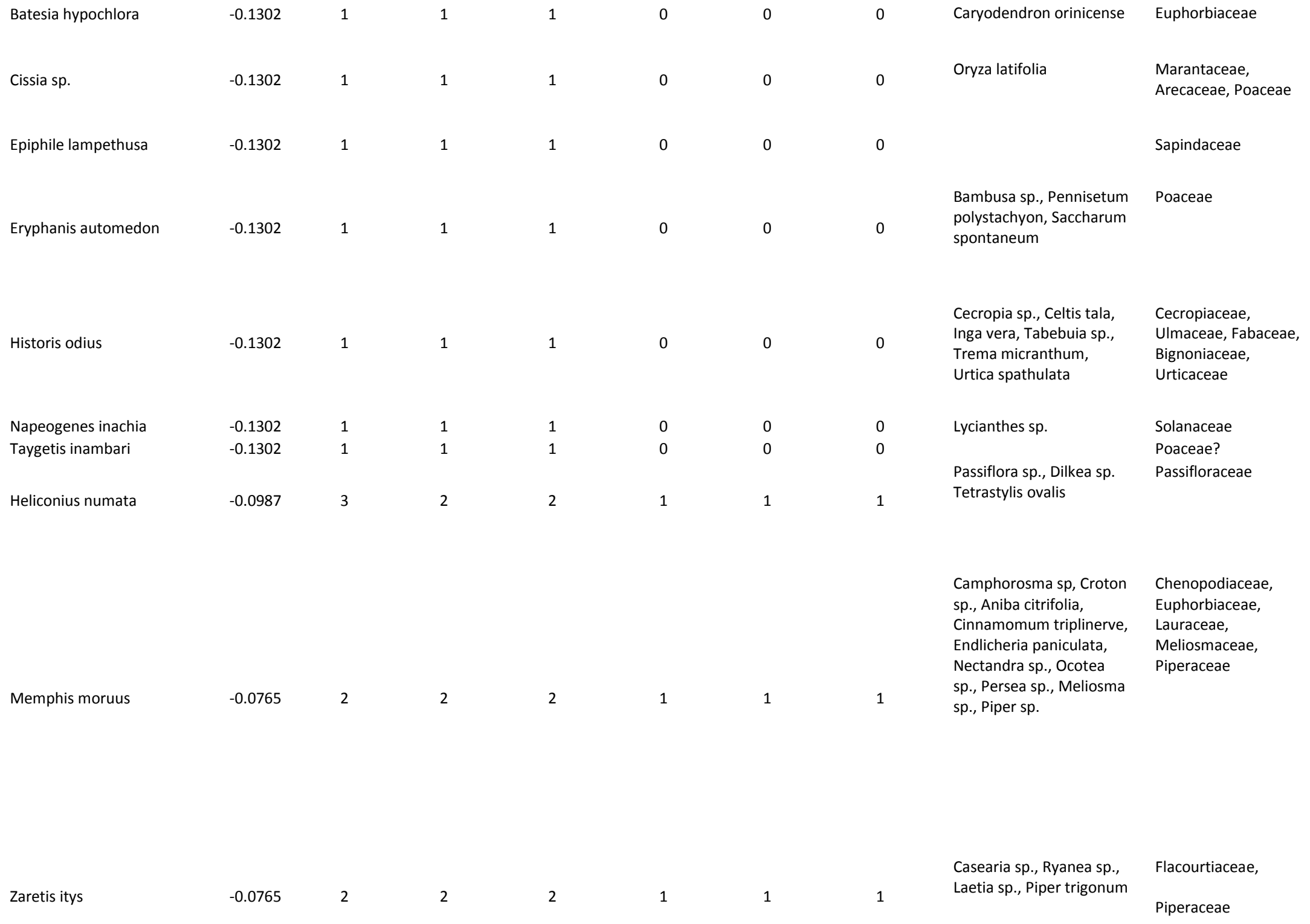




\begin{tabular}{|c|c|c|c|c|c|c|c|c|c|}
\hline Pseudodebis valentina & -0.0453 & 27 & 21 & 12 & 22 & 18 & 13 & & Poaceae \\
\hline Adelpha heraclea & 0 & 1 & 1 & 1 & 1 & 1 & 1 & Vitex sp., Piper arieianum & $\begin{array}{l}\text { Verbenaceae, } \\
\text { Piperaceae, } \\
\text { Rubiaceae }\end{array}$ \\
\hline Eunica sophonisba & 0 & 1 & 1 & 1 & 1 & 1 & 1 & Mabea sp. & Euphorbiaceae, \\
\hline Morpho deidamia & 0 & 1 & 1 & 1 & 1 & 1 & 1 & $\begin{array}{l}\text { Inga sp., Zygia latifolia, } \\
\text { Iriartea deltoidea }\end{array}$ & Fabaceae, Arecaceae \\
\hline Oleria onega & 0 & 1 & 1 & 1 & 1 & 1 & 1 & $\begin{array}{l}\text { Lycianthes sp., Solanum } \\
\text { sp. }\end{array}$ & Solanaceae \\
\hline Pyrrhogyra otolais & 0 & 3 & 3 & 3 & 3 & 3 & 3 & $\begin{array}{l}\text { Paullinia pinnata, Serjania } \\
\text { sp. }\end{array}$ & Sapindaceae \\
\hline Taygetis mermeria & 0 & 5 & 5 & 5 & 5 & 5 & 5 & & Poaceae \\
\hline Taygetis virgilia & 0.0195 & 4 & 4 & 3 & 4 & 4 & 4 & $\begin{array}{l}\text { Bambusa sp., } \\
\text { Dichorisandra amabilis, } \\
\text { Olyra sp. }\end{array}$ & $\begin{array}{l}\text { Poaceae, } \\
\text { Commelinaceae }\end{array}$ \\
\hline Memphis offa & 0.0431 & 5 & 5 & 5 & 6 & 5 & 6 & & $\begin{array}{l}\text { Piperaceae, } \\
\text { Euphorbiaceae, } \\
\text { Lauraceae, } \\
\text { Monimaceae, } \\
\text { Annonaceae }\end{array}$ \\
\hline Memphis polycarmes & 0.0519 & 3 & 3 & 3 & 4 & 4 & 4 & & $\begin{array}{l}\text { Piperaceae, } \\
\text { Euphorbiaceae, } \\
\text { Lauraceae, } \\
\text { Monimaceae, } \\
\text { Annonaceae }\end{array}$ \\
\hline Taygetis laches & 0.0613 & 11 & 9 & 9 & 13 & 13 & 11 & $\begin{array}{l}\text { Acroceras zizanioides, } \\
\text { Olyra latifolia, Oryza } \\
\text { latifolia, Panicum sp., } \\
\text { Saccarum officinarum, } \\
\text { setaria sp. }\end{array}$ & Poaceae, Arecaceae \\
\hline Caligo idomeneus & 0.0765 & 1 & 1 & 1 & 2 & 2 & 2 & $\begin{array}{l}\text { Musa acuminate, } \\
\text { Palmeria sp. }\end{array}$ & $\begin{array}{l}\text { Marantaceae, } \\
\text { Musaceae, } \\
\text { Monimiaceae }\end{array}$ \\
\hline Hypna clytemnestra & 0.0765 & 1 & 1 & 1 & 2 & 2 & 2 & Croton sp. & Euphorbiaceae \\
\hline
\end{tabular}




\begin{tabular}{|c|c|c|c|c|c|c|c|c|c|}
\hline Memphis acidalia & 0.0765 & 1 & 1 & 1 & 2 & 2 & 2 & Piper sp. & $\begin{array}{l}\text { Piperaceae, } \\
\text { Euphorbiaceae, } \\
\text { Lauraceae, } \\
\text { Monimaceae, } \\
\text { Annonaceae }\end{array}$ \\
\hline Taygetis angulosa & 0.0765 & 1 & 1 & 1 & 2 & 2 & 2 & & Poaceae? \\
\hline Panacea regina & 0.105 & 17 & 17 & 10 & 22 & 22 & 13 & & \\
\hline Colobura dirce & 0.1236 & 16 & 15 & 11 & 22 & 19 & 16 & $\begin{array}{l}\text { Cecropia sp., Cassia sp., } \\
\text { Inga sp., Cabralea } \\
\text { canjerana, Eucalyptus sp., } \\
\text { Urera baccifera }\end{array}$ & $\begin{array}{l}\text { Urticaceae, } \\
\text { Fabaceae, Meliceae }\end{array}$ \\
\hline Adelpha thesprotia & 0.1302 & 0 & 0 & 0 & 1 & 1 & 1 & $\begin{array}{l}\text { Pseudobombax } \\
\text { munguba, Cecropia sp., } \\
\text { Pourouma sp., } \\
\text { Chodanthus splendens }\end{array}$ & $\begin{array}{l}\text { Bombaceae, } \\
\text { Urticaceae, } \\
\text { Rubiaceae, } \\
\text { Bignoniaceae }\end{array}$ \\
\hline Adelpha viola & 0.1302 & 0 & 0 & 0 & 1 & 1 & 1 & Sabicea aspera & Rubiaceae \\
\hline $\begin{array}{l}\text { Archaeoprepona } \\
\text { amphimachus }\end{array}$ & 0,1302 & 0 & 0 & 0 & 1 & 1 & 1 & & $\begin{array}{l}\text { Annonaceae, } \\
\text { Malpigiaceae }\end{array}$ \\
\hline Callicore eunomia & 0.1302 & 0 & 0 & 0 & 1 & 1 & 1 & & Sapindaceae \\
\hline Catoblepia xanthicles & 0.1302 & 0 & 0 & 0 & 1 & 1 & 1 & & Araraceae \\
\hline Hamadryas feronia & 0.1302 & 0 & 0 & 0 & 1 & 1 & 1 & $\begin{array}{l}\text { Dalechampia sp., } \\
\text { Euphorbia pulcherrima, } \\
\text { Zea mays, Inga sp., } \\
\text { Syagrus romanzoffiana }\end{array}$ & $\begin{array}{l}\text { Euphorbiaceae, } \\
\text { Poaceae, Fabaceae, } \\
\text { Araraceae }\end{array}$ \\
\hline Harjesia griseola & 0.1302 & 0 & 0 & 0 & 1 & 1 & 1 & & \\
\hline Harjesia obscura & 0.1302 & 0 & 0 & 0 & 1 & 1 & 1 & & \\
\hline Heliconius erato & 0.1302 & 0 & 0 & 0 & 1 & 1 & 1 & $\begin{array}{l}\text { Passiflora sp., Dilkea sp., } \\
\text { Tetrastylis ovalis }\end{array}$ & Passifloraceae \\
\hline
\end{tabular}




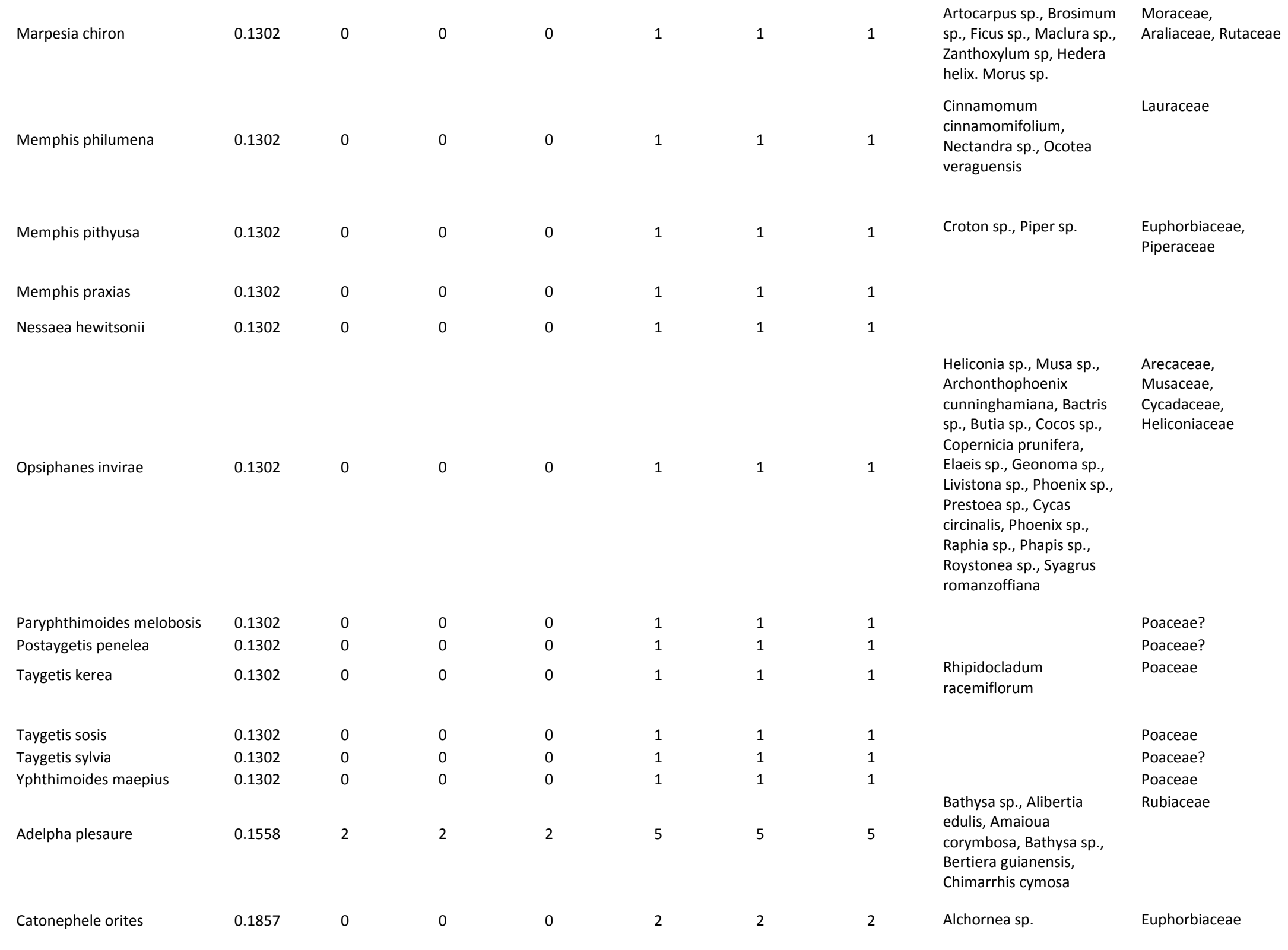




\begin{tabular}{|c|c|c|c|c|c|c|c|c|c|}
\hline Fountainea ryphea & 0.1857 & 0 & 0 & 0 & 2 & 2 & 2 & $\begin{array}{l}\text { Croton sp., Ocotea } \\
\text { acutifolia }\end{array}$ & Euphorbiaceae \\
\hline Pareuptychia metaleuca & 0.1857 & 0 & 0 & 0 & 2 & 2 & 2 & \multirow[b]{2}{*}{$\begin{array}{l}\text { Urera sp., Jacaranda } \\
\text { mimosifolia, Laportea } \\
\text { mexicanum, Myriocarpa } \\
\text { sp., Urtica } \\
\text { chamaedryoides }\end{array}$} & Poaceaea \\
\hline Smyrna blomfildia & 0.1857 & 0 & 0 & 0 & 2 & 2 & 2 & & $\begin{array}{l}\text { Bignoniaceae, } \\
\text { Urticaceae }\end{array}$ \\
\hline Paryphthimoides poltys & 0.1857 & 0 & 0 & 0 & 2 & 1 & 2 & & Poaceae \\
\hline \multirow[t]{2}{*}{ Adelpha capucinus } & 0.1891 & 1 & 1 & 1 & 5 & 5 & 4 & $\begin{array}{l}\text { Mansoa difficilis, Bombax } \\
\text { sp., Pachira aquatica, } \\
\text { Cecropia sp., }\end{array}$ & $\begin{array}{l}\text { Bignoniaceae, } \\
\text { Bombaceae, } \\
\text { Urticaceae }\end{array}$ \\
\hline & & & & & & & & $\begin{array}{l}\text { Paragonia pyramidata, } \\
\text { Erythroxylum sp., } \\
\text { Heliconia bihai, Gleditsia } \\
\text { sp., Pithecellobium sp., } \\
\text { Andira enermis, Arachis } \\
\text { hypogaea, Dahlstedtia } \\
\text { pinnata, Dalbergia sp., } \\
\text { Dioclea sp., Erythrina sp., } \\
\text { Lonchocarpus sp., Inga }\end{array}$ & $\begin{array}{l}\text { Bignoniaceae, } \\
\text { Fabaceae, } \\
\text { Erythroxylaceae, } \\
\text { Heliconiaceae, } \\
\text { Malpighiaceae, } \\
\text { Musaceae, } \\
\text { Ochnaceae, } \\
\text { Rubiaceae, } \\
\text { Sapindaceae }\end{array}$ \\
\hline Morpho achilles & 0.1961 & 2 & 2 & 2 & 6 & 5 & 6 & $\begin{array}{l}\text { sp., Machaerium sp., } \\
\text { Mucuna sp., Myrocarpus } \\
\text { sp, Platymiscium sp., } \\
\text { Pterocarpus sp., } \\
\text { Rhyncosia edulis, Robinia } \\
\text { sp., Swartzia sp., } \\
\text { Heteropterys laurifolia, } \\
\text { Musa sp., Ouratea lucens, } \\
\text { Genipa americana, } \\
\text { Pallinea pinnata }\end{array}$ & \\
\hline Consul fabius & 0.2222 & 1 & 1 & 1 & 5 & 5 & 5 & Casearia sp., Piper sp., & $\begin{array}{l}\text { Flacourtiaceae, } \\
\text { Piperaceae }\end{array}$ \\
\hline Adelpha jordani & 0.2228 & 29 & 29 & 12 & 61 & 60 & 19 & Vitex trifolia & Verbenaceae \\
\hline Memphis xenocles & 0.2232 & 0 & 0 & 0 & 4 & 4 & 3 & Croton sp. & Euphorbiaceae, \\
\hline Nica flavilla & 0.2294 & 0 & 0 & 0 & 3 & 3 & 3 & $\begin{array}{l}\text { Cardiospermum sp., } \\
\text { Serjania sp., Paullinia sp. }\end{array}$ & Sapindaceae \\
\hline
\end{tabular}


Memphis glauce

0.2406

Archaeoprepona demophon

0.2677

17

0.2954

Adelpha iphiclus

0.3025

Zaretis isidora
8

8

8

Chrysobalanus icaco, Hirtella racemosa, Licania

arborea, Inga sp., Zygia longifolia, Andira inermis,

Psidium sp., Coffea

arabica, Melicoccus

bijugatus
14

Anaxagorea crassipetala,
Annona sp., Rourea
glabra, Maripa
panamanensis, Lacistema
aggregatum, Nectandra
purpurea, Ocotea sp.,
Persea americana,
Malpighia glabra, Guarea
sp., Mollinedia sp.,
Siparuna sp., Brosimum
gaudichaudi, Triplaris sp.,
Theobroma cacao,
Hybanthus sp.

Alseis blackiana, Antirhea
trichantha, Bathysa sp,
Calycophyllum sp, Isertia
haenkeana, Rondeletia
panamensis, Sipanea sp,
Uncaraia sp.
Casearia sp., Colubrina
sp.

sp.
Chrysobalanaceae,

Fabaceae,

Myrtaceae,

Rubiaceae,

Sapindaceae

Piperaceae,

Euphorbiaceae,

Lauraceae,

Monimacea,

Annonaceae?

Annonaceae,

Connaraceae,

Convulvaceae,

acistematataceae,

Lauraceae,

Malpighiaceae,

Meliaceae,

Monimiaceae,

Moraceae,

Polygonaceae,

Sterculiaceae,

Violaceae

Rubiaceae

7

Flacourtiaceae, 


\begin{tabular}{|c|c|c|c|c|c|c|c|c|c|}
\hline Morpho helenor & 0.3442 & 2 & 2 & 2 & 13 & 10 & 10 & $\begin{array}{l}\text { Machaerium sp., } \\
\text { Pterocarpus sp., } \\
\text { Lonchocarpus sp., } \\
\text { Platymiscium sp, Swartzia } \\
\text { sp., Mucuna sp., } \\
\text { Myrocarpus sp, Erythrina } \\
\text { sp., Inga sp., Dahlstedtia } \\
\text { sp. }\end{array}$ & $\begin{array}{l}\text { Fabaceae, } \\
\text { Mimosaceae }\end{array}$ \\
\hline Temenis laothoe & 0.3537 & 2 & 2 & 2 & 16 & 16 & 10 & $\begin{array}{l}\text { Stigmaphyllon sp., } \\
\text { Allophylus edulis, } \\
\text { Cardiospermum sp, } \\
\text { Paullinia sp., Serjania sp., } \\
\text { Urvillea sp. }\end{array}$ & $\begin{array}{l}\text { Malpighiaceae, } \\
\text { Sapindaceae }\end{array}$ \\
\hline Pyrrhogyra amphiro & 0.3563 & 0 & 0 & 0 & 8 & 7 & 7 & & Sapindaceae? \\
\hline Pyrrhogyra crameri & 0.3912 & 2 & 2 & 2 & 18 & 18 & 12 & $\begin{array}{l}\text { Paullinia sp., Serjania } \\
\text { mexicana }\end{array}$ & Sapindaceae \\
\hline
\end{tabular}

